\section{Applications of Computer} Technology in Distance

Education:

The Case of the Open Learning Institute

by Ian Mugridge

The Open Learning Institute of British Col-
umbia (OLI) is a publicly funded, distance education institution, delivering programmes and courses throughout the pro-
vince. It was set up by order-in-council of the provincial government in June, 1978
and given a mandate to deliver 'by distance and given a mandate to deliver 'by distance
means' programmes in the three areas of vocational education and undergraduat degrees in arts and science. From this has developed to the point where, beginning with seven courses and 750 student in its first, pilot semester in September,
1979 , it now offers over a hundred and fift 1979, it now offers over a hundred and fitty
courses in its three programmes and will have just over 16,000 course enrollments during the 1984-85 fiscal year. The number new programmes, particularly in the brought into being; and the enrollments are also increasing, though at a somewh slower rate than in the past. (For an ac-
count of the early years of OLI see Ellis \&

The application of various kinds of tech-
nology to distance education is a much di cussed problem, made more complex by
the fact that distance education is itself new technology, a new method for dev dents who are "at a distance", howeve
that distance is defined (See Bates, 1984 It involves the use of a variety of medi print, audio tapes and radio, video tapes
and television, teleconferencing and number of computer applications - as well
as more conventional forms of learning as more conventional forms of learning
such as personal interaction between teacher and learner and written commentary on written assignments. The mix of
such ingredients varies from course to Ian Mugridge is Dean of Academic Af7671 Alderbridge Way, Richmond, B.C. V6X 1Z9. material, the objectives of the course or unit, the type of learner or learning in-
volved and so on. It follows then, that there sno single prescription for using any particular medium of instruction, no single way of putting a variety of media together to as-
sist effective learning sist effective learning.

OLI, which is a unique educational insty to tion in that it is the only distance education operation which combines within a
single organization all levels of pre- and single organization all levels of pre- and
post-secondary education. Within the three programmes mentioned earlier, courses programmes mentioned earlier, courses
have been or are bing developed in areas
as diverse as English as a second language as diverse as English as a second language
and Shakespeare, introductory computing and Shakespeare, introductory computing
and advanced mathematics and in subjects practical courses in nursing, electronics and travel counselling. Clearly, teaching and learning methods, learners objectives
and expectations in such a wide variety of subjects and levels must be expected to cover a very wide spectrum; and the
courseware developed to meet these needs must reflect this fact. Course development sumption.
It has to be admitted that the consideration given to the use of a variety of media not always been as extensive as it migh have been. The national tendency to stay with familiar techniques of demonstrated effectiveness is present in all educational new ways. The more practical consideration of cost also restricts, particularly in a period of uncommon restraint, the use of
some of the more elaborate and expensive

media.
Nevertheless, the institute has made and
will increasingly akse contributions to the will increasingly make contributions to the
use of a variety of media. Experiments are use of a variety of media. Experiments are
being conducted with the use of live interactive television though this is still being undertaken on a very limited basis. (In this area, major attention should be given to the
psychology courses offered in this mode by low. This system, which runs at OLI on a
VAX $11 / 750$ has attracted a great deal of other parts of the world (See Pates, 1984);

course and even from unit to unit within North Island College in B.C., courses live interactive television to this point in Canada.l Audio tapes are being used in-
creasingly and with growing effectiveness nareas as diverse as language teaching (in-
cluding the teaching of English as a second language/ and a senior university level Shakespeare course where audio tapes are being used to deronstrate the effectivenes strate activities as various as experiments in high school biology and methods of mechanics course. Such experimotive being combined with continued use of print materials which still form the basis ed, however, that developments in the next ew years will affect this balance in major ways. Nowhere is this potential greater
han in areas where computers can be usthan in areas where computers can be us-
ed as an aid to instruction. Before turning to this matter, I will deal with computer applications in the manage-
ment of distance education and in the development of distance education materials. Both of these are areas of great importance have been made in recent years. There is no sign that the speed and magnitude of
such advances will diminish in the foreseesuch advances will diminish in the foreseeIn the area of management of distance package known as the Distance Education pects of student admission and records utor payroll, assignment grading and ex$\mathrm{m}$ scheduling, transcript preparation and dent comnting and to students, sturequirements. An enhancement to this system which is almost complete is the Course Management Inventory System DETREMS struct the warehouse to ship course materals to students registering, adjust inventory
figures and flag courses in which stock is VOLUME 14, NUMBER 1, 1985 passage. Television is being used to demonand Training Resource Management Sys interest not only in Canada but also in er advances, for plans are already being ity of the existing sy ent evaluation and management system, to build links to an integrated courseware
authoring, production and distribution sysauthoring, production and distribution sysmanagement system.

1984). antly to the institute's effectiveness and efficiency in the areas where they operate. As the new systems are being tested and effective, plans are also being made for modifications and additions. It is hope hat, within the next three years, a system
will emerge to link the existing DETREMS and course development systems with new $p$ an integrated system which will combine the development, production and distribution systems as well as those for studment of all these activities. Given anagepriate support, this ambitious goal will become a very practical possibility. In addi-
tion to this extensive work in the use of computers to manage distance education,
OLI has also undertaken a good deal of work in the direct instructional uses of computers and computer-related tech-
niques. The videotex system known as niques. The videotex system known as
TELIDON, which will, if widely used, make banks of information available to students through home television, has been evaluated and experiments begun with its
use in a computer-aided learning mode (Love, 1982). The results of such mode ments are being added to the data supplied to those being carried on at other institutions and will influence the direction of future work in this area (For a discussion
and summary of such work see Kaufman 1984). It remains to outline briefly the activities
which are being undertaken in direct instructional areas. Little instruction in comexperiment in this area was the development of a basic computing course using homes. This nore delivered to students' homes. This non-credit course was ex-
tremely successful and was discontinued only when the equipment and material became obsolete (Kaufman \& Meakin, 1982). Apart from this, however, the institute has not solved the problem of delivering practi-
cal computing instruction at a distance to those students who require more advanced applications. It is likely that widespread
implementation of hands-on computing inimplementation of hands-on computing in-
struction will have to await the greater struction will have to await the greater
availability of microcomputers and other conditions necessary for distant students
to enter this area in large numbers to enter this area in large numbers.
In the area of computer-aided learnin work is in progress on two major projects which will demonstrate the potential of CAL for distant learnerrs. The pirst of these
is a package for instruction at the seconOLI working on courses to be The use of a common course format ensures the ability for both institutions readi-
ly to use each other's material (Timmers CANADIAN JOURNAL OF EDUCATIONAL COMMUNICATION dary school level on food and nutrition in conjunction with the Certified General Accountants of Canada and McGraw-Hil

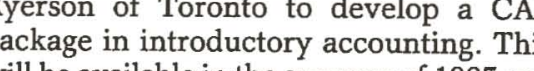
will be available in the summer of 1985 an his type of instruction. Both of these projects should provide extensive data on With these developments and with the admation systems sond on management inforareas to existing degree programmes, ther is litle doubl that the institute's involve. all aspects of distance education will continue and grow.

References

ates, A. W. (1984). The role of technology in distance education. London Cooper, D. W., \& Thompson, J. R. (1982). word manipulation. In J. S. Daniel, M. A. Stroud, \& J. R. Thompson (Eds.J
Learning at a Distance: A World Learning at a Distance: A World
Perspective (pp. 301-302). Edmonton illis, J. F., \& Mugridge, I. (August 1983). The Open Learning Institute of British Columbia: A case study. The Open
University Distance Education Research Group Papers, (8). fman, D. (1984). A computer-based

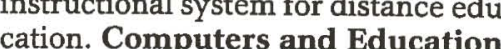
8, (4), 479-484.
ufman, D. \& Meakin, D. (1982).
Delivery of a home-based course in personal computing. Paper present Love, L. (1982). Use of TELIDON for computer-aided learning in dismanuscript Open. Unpublished of British Columbia. s. (1984). VAX offers resource
management for distance education. management for distance education.
EDU Magazine, $\mathbf{3 5}, 16$. mmers, S. (1983). Use of electronic mail to develop an Open Learning
Institute chemistry course. Unpublished manuscript, Open Learning immers, S. (1984). Distance education Over the rainbow. EDU Magazine,

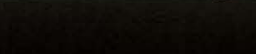

